\title{
Efektivitas Modul Pusat Informasi dan Konseling tentang Seks Bebas pada Siswa SMA Surabaya
}

\author{
Ella Novita Sari, Sri Widati \\ Departemen Promosi Kesehatan dan Ilmu Perilaku \\ Fakultas Kesehatan dan Masyarakat Universitas Airlangga Surabaya \\ Alamat Korespondensi: \\ Ella Novita Sari, ellans1150@gmail.com
}

\begin{abstract}
Surabaya is one of the city that has a number of free sex in adolescents. One of the activities of BKKBN is Pusat Informasi and Konseling Remaja (PIK), which one of its activities is using a module of adolescent reproductive health, sexuality and adolescent problems as a media of information and education for adolescents about the menace of sex behavior as the effort to mitigate and reduce the number of free sex and it to conduct the activities to reduce and prevent adolescent problems, which commonly called TRIAD KRR that consists of drug problems, $H I V-A I D S$, and free sex. SMA Surabaya is one of the schools that had 3 cases of free sex in 2012. The aim of this study was to determine the effectiveness of the module of PIK on adolescent reproductive health, sexuality and free sex of adolescents in changing the attitudes of the students in one of the high school in Surabaya about free sex. This research is a study with one group pretest-posttest design were carried out on 80 students were selected. The statistical test used was paired sample T test. The results showed that the level of respondents' attitudes decreased, which were the pre-test $(p=50.3500)$ and post-test $(p=50.0625)$ and it was not significant, which means there was no difference between the pre-test and post-test $(p=0.659)$. The module had not been effective in improving the attitude of students in one of high school in Surabaya on reproductive health, sexuality, and free sex of adolescents.
\end{abstract}

Keywords: effectiveness, module, pusat informasi and konseling

\begin{abstract}
ABSTRAK
Angka seks bebas remaja di Surabaya tinggi. Pusat Informasi dan Konseling Remaja (PIK) yang menggunakan modul tentang kesehatan reproduksi remaja, seksualitas dan permasalahan remaja sebagai media informasi dan pembelajaran bagi remaja tentang bahaya perilaku seks bebas merupakan upaya untuk mengurangi angka seks bebas dan mencegah permasalahan remaja yang terdiri dari masalah NAPZA, HIV-AIDS, dan seks bebas. SMA Surabaya adalah salah satu sekolah yang terdapat 3 kasus seks bebas pada tahun 2012. Penelitian ini bertujuan untuk mengetahui efektivitas modul tentang kesehatan reproduksi remaja, seksualitas dan permasalahan remaja dalam mengubah sikap siswa-siswi di salah satu Sekolah Menengah Atas di Surabaya tentang seks bebas. Penelitian ini menggunakan one grup pretest-posttest design pada 80 siswa yang terpilih. Uji statistik yang digunakan adalah uji T sampel berpasangan. Hasil penelitian menunjukkan bahwa tingkat sikap responden menurun yaitu pre-test $(\mathrm{p}=50,3500)$ dan post-test $(\mathrm{p}=50,0625)$ dan tidak signifikan yang berarti tidak memiliki perbedaan antara pre-test dan post-test $(\mathrm{p}=0,659)$. Modul belum efektif dalam meningkatkan sikap siswa-siswi salah satu SMA di Surabaya tentang kesehatan reproduksi, seksualitas, dan seks bebas remaja.
\end{abstract}

Kata kunci: efektivitas, modul, pusat informasi dan konseling

\section{PENDAHULUAN}

Remaja rentan terhadap masalah sosial yang berdampak pada aspek kesehatan. Terjadi proses transisi kehidupan dari masa anak-anak menuju masa dewasa pada remaja sehingga remaja cenderung mengalami banyak perubahan baik fisik, psikis, dan sosial yang dapat dipengaruhi oleh lingkungan sekitar yang berdampak pada perilaku remaja dalam kehidupan sehari-hari (Notoadtmojo, 2007).

Terdapat 20,2 juta remaja pria dan 19,1 juta remaja wanita usia 15-24 tahun dengan status belum kawin di Indonesia berdasarkan data Sensus Penduduk 2010. Remaja di Indonesia memiliki beberapa permasalahan sosial yang 
berdampak pada aspek kesehatan. Remaja Indonesia merupakan aset yang penting dalam pembangunan nasional. Remaja memiliki jumlah yang lebih banyak daripada jumlah balita, jumlah anak, jumlah orang dewasa, dan jumlah lansia. Namun remaja saat ini cenderung berisiko terhadap masalah perilaku seksual pranikah, NAPZA dan HIV/AIDS (Data Kajian Profil Penduduk Remaja 2011). Remaja perlu mendapatkan perhatian dan bimbingan khusus baik dari orang tua maupun pihak dari sekolah agar remaja mampu menjadi remaja yang tidak hanya berkualitas secara pengetahuan namun juga secara iman dan akhlaq.

Terdapat banyak permasalahan mengenai remaja yang memiliki perilaku seks bebas (Kajian Profil Penduduk Remaja 2011). Perilaku tersebut dikarenakan pergaulan sekarang yang makin tidak terkontrol. Terdapat perbedaan nyata antara persepsi dan perilaku remaja pada data SDKI KRR 2007 dan SDKI KRR 2012. Hal tersebut ditunjukkan sebagai berikut yaitu persepsi remaja pria dan remaja wanita tentang pentingnya mempertahankan keperawanan yaitu pada tahun 2007 sebanyak (99\%) remaja wanita dan (98\%) remaja pria setuju mempertahankan keperawanan berkurang menjadi $(77 \%)$ remaja wanita dan (66\%) remaja pria pada tahun 2012. Awal mulai berpacaran sebelum umur 15 tahun menunjukkan pada 2007 sebesar (19\%) remaja pria dan $(24 \%)$ remaja wanita mulai berpacaran sebelum umur 15 tahun, meningkat menjadi sebesar $(28 \%)$ remaja pria dan $(27 \%)$ remaja wanita mulai berpacaran sebelum umur 15 tahun (SDKI KRR 2012).

Aktivitas berpacaran remaja pada data SDKIKRR 2012 menunjukkan berpegangan tangan merupakan aktivitas berpacaran yang paling banyak mereka lakukan yaitu (80\%) remaja pria dan $(72 \%)$ remaja wanita, kemudian berciuman (48\%) remaja pria dan (30\%) remaja wanita, dan meraba bagian tubuh yang sensitif (30\%) remaja pria dan $(6 \%)$ remaja wanita. Peningkatan ini menunjukkan bahwa remaja saat ini cenderung memiliki bersikap perilaku seks bebas. Remaja di Jabodetabek telah melakukan hubungan seks pranikah sebesar (51\%) menurut data BKKBN 2010. Terdapat remaja yang juga melakukan seks pranikah yaitu di Bandung sebesar (47\%), Medan $(52 \%)$, dan Yogyakarta mengalami kehamilan sebelum menikah sebesar (37\%) (BKKBN dalam Saragih, 2015).

Soetjiningsih (2006), menyatakan bahwa terdapat banyak faktor baik dari dalam diri remaja maupun lingkungan remaja yang mendukung remaja memiliki perilaku seks bebas. Lingkungan yang salah menyebabkan remaja terjerumus pada seks bebas, seperti contoh remaja yang sedang berpacaran cenderung memiliki perilaku seks bebas karena remaja memiliki karakteristik yang suka mencoba hal-hal baru dan remaja saat ini lebih tidak membatasi pergaulan pada diri mereka. Faktor lain adalah ekonomi seperti butuh biaya untuk sekolah, butuh biaya untuk hidup namun ekonomi keluarga tidak memungkinkan, sehingga mendesak remaja melakukan seks bebas untuk memenuhi kebutuhan dirinya dan keluarganya. Faktor lain yang juga mempengaruhi perilaku remaja adalah kasih sayang dan perhatian orang tua. Sebagai remaja yang masih mencari jati diri sesungguhnya, yang remaja ketahui orang tua adalah satu-satunya sosok yang diharapkan mampu memberikan kasih sayang dan perhatian pada anaknya. Namun terkadang terjadi komunikasi yang tidak baik antara remaja dan orang tua sehingga remaja cenderung merasa terabaikan dan salah dalam bergaul. Sebagai contoh beberapa kasus, remaja melakukan seks bebas untuk mencari kesenangan dan mencari pelarian penyelesaian masalah, serta masih tingginya rasa tabu orang tua dalam memberikan informasi terkait seks bebas pada anak remajanya.

PIK merupakan program Penyiapan Kehidupan Berkeluarga bagi Remaja (PKBR) yang didirikan oleh Badan Kependudukan dan Keluarga Berencana Nasional (BKKBN). Sebagai wakil pemerintah yang sadar perlu suatu program yang memfasilitasi remaja sehingga mampu membuat remaja memahami dan mempraktikkan perilaku hidup sehat dan berakhlak untuk mencapai ketahanan remaja. BKKBN mengadakan kegiatan PIK untuk dikelola dari, oleh, dan untuk remaja dalam memberikan pelayanan informasi dan konseling tentang kesehatan reproduksi serta kegiatan penunjang lainnya agar remaja diharapkan tidak terjebak pada penyalahgunaan NAPZA, HIV dan AIDS maupun seks bebas remaja yang menyebabkan kehamilan tidak diinginkan 
serta mempromosikan perencanaan kehidupan berkeluarga dengan sebaik-baiknya (BKKBN, 2006).

Kegiatan PIK menggunakan modul sebagai media untuk memberikan materi dan informasi tentang kesehatan reproduksi remaja, seksualitas dan permasalahan remaja yang dikeluarkan oleh Badan Pemberdayaan Masyarakat dan Keluarga Berencana (BAPEMAS \& KB) Kota Surabaya bersama Dinas Pendidikan Kota Surabaya dan LSM Genta Surabaya pada tahun 2015. Modul ini bertujuan agar remaja mampu memahami tentang perkembangan dan pertumbuhan manusia, reproduksi dan seksualitas, body image, serta mampu mengidentifikasi permasalahan yang mungkin terjadi pada masa remaja dan menghadapi permasalahan tersebut.

Modul dengan judul "Modul Pelatihan Dan Perlindungan Anak Berbasis Sekolah" memiliki 10 BAB materi. Materi tersebut antara lain Pembentukan Kelompok Perlindungan Anak di Sekolah, Perkembangan Manusia, Kesadaran dan Identitas Diri, Pengenalan Hak Anak, Keterampilan Hubungan Antarindividu, Kreativitas Anak Masa Kini, Keterampilan Menghadapi Masalah, Gender dan Budaya Masyarakat, Menjaga Diri Tetap Sehat, dan Persiapan Pengembangan Karier. Modul ditujukan bagi Guru BK dan Siswa SMP/MTs/ SMA/MA/SMK melalui kegiatan Konselor Sebaya dalam Pusat Informasi dan Konseling Remaja.

Penelitian ini di fokuskan pada BAB II yaitu Perkembangan Manusia yang terdapat informasi terkait pertumbuhan dan perkembangan manusia sampai pada masa remaja. Modul merupakan bahan ajar yang disusun secara sistematis dan menarik dengan bahasa yang mudah dipahami oleh siswa. Modul yang mencakup isi materi, metode dan evaluasi yang dapat digunakan secara mandiri sesuai umur dan tingkat pengetahuan siswa agar dapat belajar secara mandiri. (Andi Prastowo, 2012).

Modul memiliki beberapa karakteristik yang harus dipenuhi untuk mendukung tersampaikannya suatu informasi kepada siswa. Modul yang baik harus memperhatikan lima karakteristik yaitu self instruction, self contained, stand alone, adaptif, dan userfriendly (Direktorat Pembinaan Sekolah Menengah Kejuruan 2008).
Belajar dengan menggunakan modul terdapat banyak manfaat yaitu siswa dapat bertanggung jawab dan belajar sesuai dengan tingkat kemampuannya.

Terdapat PIK sejak tahun 2010 di salah satu SMA Surabaya namun masih terdapat 3 kasus seks bebas pada tahun ajaran 2012/2013 pada siswa-siswi SMA Surabaya. Penelitian ini dimaksudkan untuk mengetahui efektivitas penggunaan modul tentang kesehatan reproduksi remaja, seksualitas dan permasalahan remaja dengan judul "Modul Pelatihan Anak Perlindungan Anak Berbasis Sekolah" yang difokuskan pada BAB II yaitu Perkembangan Manusia dalam mengubah sikap siswa SMA Surabaya tentang seks bebas.

\section{METODE PENELITIAN}

Penelitian ini merupakan penelitian dengan one group pre-test post-test design. Penelitian dilakukan di salah satu Sekolah Menengah Atas Surabaya. Waktu penelitian berlangsung selama \pm 1 bulan. Responden penelitian ini didapatkan melalui teknik simple random sampling dengan jumlah 80 siswa.

Pengumpulan data berupa pengumpulan data primer dan data sekunder. Pengumpulan data primer dilakukan dengan menggunakan lembar kuesioner berupa pre-test dan post-test serta memberikan modul tentang seks bebas kepada responden. Pengumpulan data sekunder berupa mengutip dari hasil penelitian pada website, buku, peraturan undang-undang, dan artikel. Analisis hasil data yang digunakan adalah uji T-test sampel berpasangan (paired sample T-test).

\section{HASIL PENELITIAN}

\section{Karakteristik Siswa SMA Surabaya}

Karakteristik siswa SMA Surabaya terdiri dari umur, jenis kelamin, tingkat kelas, pendidikan terakhir orang tua, dan uang saku perhari siswa SMA dapat dilihat pada tabel 1 . Karakteristik umur responden SMA Surabaya 2016 terdiri dari siswa berumur 17-19 tahun dan sebesar $(60 \%)$ siswa berumur 17 tahun. Siswa SMA Surabaya sebesar (77\%) adalah berjenis kelamin perempuan. Tingkatan kelas siswa SMA 
Tabel 1. Karakteristik Siswa SMA Surabaya

\begin{tabular}{llrr}
\hline \multicolumn{1}{c}{ Variabel } & \multicolumn{1}{c}{ Kategori } & F & \% \\
\hline \multirow{3}{*}{ Usia } & 17 Tahun & 48 & 60 \\
& 18 Tahun & 28 & 35 \\
\multirow{2}{*}{ Jenis Kelamin } & 19 Tahun & 4 & 5 \\
\hline \multirow{2}{*}{ Tingkat Kelas } & Laki-laki & 18 & 23 \\
& Perempuan & 62 & 77 \\
\hline \multirow{5}{*}{ Pendidikan Terakhir Orang Tua } & Kelas XI & 43 & 54 \\
Ayah & Kelas XII & 37 & 46 \\
& SD & 19 & 24 \\
& SMP & 16 & 20 \\
& SMA & 26 & 32 \\
& Perguruan Tinggi & 1 & 2 \\
& Tidak Sekolah & 0 & 0 \\
& Tidak Tahu & 18 & 22 \\
\hline \multirow{5}{*}{ Ibu } & SD & 30 & 37 \\
& SMP & 13 & 16 \\
& SMA & 14 & 17 \\
& Perguruan Tinggi & 1 & 2 \\
& Tidak Sekolah & 1 & 2 \\
Uang saku per hari & Tidak Tahu & 21 & 26 \\
\hline & $<$ Rp8750 & 34 & 42 \\
& Rp8750-Rp17450 & 43 & 54 \\
\hline
\end{tabular}

Surabaya 2016 terdiri dari (54\%) kelas XI dan $(46 \%)$ kelas XII. Tingkat pendidikan terakhir orang tua siswa SMA Surabaya terdiri dari SD, SMP, SMA, Perguruan Tinggi, Tidak Tahu, dan Tidak Sekolah dan sebagian besar $(60 \%)$ orang tua siswa SMA Surabaya pernah mengenyam pendidikan. Sebanyak (54\%) siswa SMA Surabaya memiliki uang saku per hari berkisar antara Rp8750-Rp17450.

\section{Perbedaan Tingkat Sikap Siswa SMA Surabaya antara Pre-test dan Post-test}

Distribusi tingkat sikap siswa SMA Surabaya tentang seks bebas antara pre-test dan post-test 2016 dapat dilihat pada tabel 2. Tingkat sikap siswa SMA Surabaya tentang seks bebas dibagi menjadi 3 (tiga) kategori antara lain kategori kurang dengan rentang nilai $(\mathrm{p}=15-30)$, kategori cukup dengan rentang nilai $(p=31-45)$, dan kategori baik dengan rentang nilai $(\mathrm{p}=46-60)$. Berikut adalah tabel tingkat sikap siswa SMA Surabaya antara pre-test dan post-test.
Tabel 2 menunjukkan tingkat sikap siswa SMA Surabaya antara pre-test dan post-test 2016 yaitu tidak terdapat perbedaan pada kategori kurang, terdapat perbedaan pada kategori cukup yaitu mengalami penurunan nilai, dan terdapat perbedaan pada kategori baik yaitu

Tabel 2. Perbedaan Tingkat Sikap Siswa SMA Surabaya antara Pre-test dan Post-test tentang Seks Bebas 2016

\begin{tabular}{lcc}
\hline \multicolumn{1}{c}{ Kategori } & F & \\
\hline Kurang & 1 & \% \\
Cukup & 14 & 1 \\
Baik & 65 & 17 \\
Total & $\mathbf{8 0}$ & 82 \\
\multicolumn{1}{c}{ Kategori } & Post test & $\mathbf{1 0 0}$ \\
\hline Kurang & F & \\
Cukup & 1 & 1 \\
Baik & 7 & 9 \\
Total & 72 & 90 \\
\hline
\end{tabular}


mengalami peningkatan, sehingga dapat disimpulkan bahwa tingkat sikap responden SMA Surabaya antara pre-test dan post-test 2016 mengalami sedikit peningkatan dan sebagian besar tingkat sikap responden SMA Surabaya tentang seks bebas pada masyarakat berada dalam kategori yang baik.

\section{Analisis Perbedaan Sikap tentang Seks Bebas Remaja antara Pre-test dan Post-test 2016}

Terdapat dua analisis hasil uji statistik sikap tentang seks bebas remaja siswa SMA Surabaya antara pre-test dan post-test. Analisis statistik uji $\mathrm{T}$ sampel berpasangan dengan melihat nilai rata-rata tingkat sikap pada saat pre-test dan pada saat post-test dan analisis perbedaan sampel berpasangan dengan melihat tingkat signifikan sikap antara pre-test dan post-test. Analisis dilakukan dengan menggunakan uji $\mathrm{T}$ sampel berpasangan. Berikut hasil analisis statistik sampel berpasangan dengan melihat nilai ratarata tingkat sikap antara pre-test dan post-test siswa SMA Surabaya pada tabel 3.

Pada tabel 3 dapat diketahui hasil nilai ratarata tingkat sikap antara pre-test dan post-test siswa SMA Surabaya menggunakan uji T sampel berpasangan yaitu pada pre-test $(\mathrm{p}=50,3500)$ pada post-test menjadi $(\mathrm{p}=50,0625)$ sehingga tingkat sikap siswa SMA Surabaya mengalami penurunan. Sedangkan tabel 4. merupakan hasil analisis perbedaan sampel berpasangan dengan melihat tingkat signifikan sikap antara pre-test dan post-test. Berikut adalah hasil analisis perbedaan sampel berpasangan dengan melihat tingkat signifikan sikap antara pre-test dan post-test pada Tabel 4.

Tabel 3. Hasil Analisis Statistik Sampel Berpasangan dengan Melihat Nilai Rata-Rata Tingkat Sikap Antara Pre-Test Dan Post-Test Siswa SMA Surabaya

\begin{tabular}{lcccc}
\hline & $\begin{array}{c}\text { Nilai } \\
\text { rata- } \\
\text { rata }\end{array}$ & Jumlah & $\begin{array}{c}\text { Standar } \\
\text { Deviasi }\end{array}$ & $\begin{array}{c}\text { Std. } \\
\text { Rata- } \\
\text { rata } \\
\text { eror }\end{array}$ \\
\hline pretestsikap & 50,3500 & 80 & 5,66825 &, 63373 \\
postestsikap & 50,0625 & 80 & 5,99017 &, 66972 \\
\hline
\end{tabular}

Tabel 4. Hasil Analisis Perbedaan Sampel Berpasangan Dengan Melihat Tingkat Signifikan Sikap Antara Pre-test Dan Post-test Siswa SMA Surabaya

\begin{tabular}{lcccc}
\hline & Perbedaaan & & df & $\begin{array}{c}\text { Sig. } \\
\text { (2-arah) }\end{array}$ \\
\hline $\begin{array}{l}\text { Rata-rata } \\
\text { postestsikap- }\end{array}$ & .28750 & .442 & 79 & .659 \\
\hline
\end{tabular}

Tabel 4 menunjukkan hasil analisis perbedaan sampel berpasangan dengan melihat tingkat signifikan sikap antara pre-test dan post-test siswa SMA Surabaya menunjukkan nilai Sig. sebesar $(p=0,659)>(\alpha=0,05)$ sehingga dapat disimpulkan bahwa tingkat sikap siswa SMA Surabaya antara pre-test dan post-test tidak signifikan.

Selain melihat hasil analisis dengan menggunakan uji $\mathrm{T}$ sampel berpasangan, terdapat penilaian untuk menentukan efektivitas modul PIK tentang kesehatan reproduksi remaja, seksualitas, dan permasalahan remaja. Penilaian tersebut dengan melihat respons siswa SMA Surabaya terhadap konten yang ada pada modul PIK. Penilaian menggunakan pedoman berdasarkan modul dengan kriteria yang baik menurut Direktorat Pembinaan Sekolah Menengah Kejuruan tahun 2008. Konten yang dinilai oleh siswa SMA Surabaya yaitu tujuan yang dirumuskan, materi pembelajaran, contoh pada materi, kesesuaian modul dengan usia responden, bahasa yang digunakan, rangkuman materi pembelajaran, dan penambahan ilustrasi. Berikut penilaian siswa SMA Surabaya terhadap konten modul PIK pada gambar 1-10 di bawah ini.

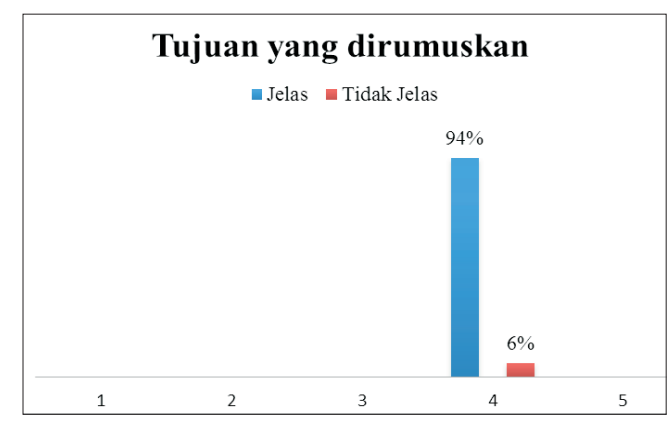

Gambar 1. Penilaian Siswa SMA Surabaya tentang Tujuan yang dirumuskan pada Modul PIK. 


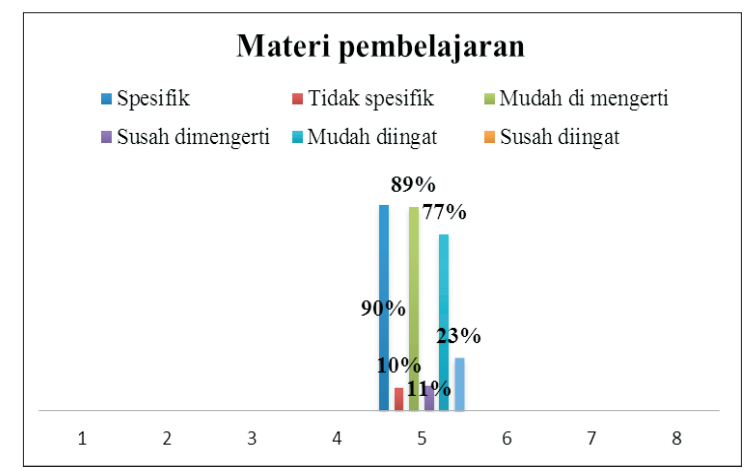

Gambar 2. Penilaian Siswa SMA Surabaya tentang Materi Pembelajaran pada Modul PIK.

Gambar 1 merupakan hasil penilaian siswa SMA Surabaya tentang tujuan yang dirumuskan pada modul PIK. Berikut gambar 1 tentang tujuan yang dirumuskan pada modul PIK.

Berdasarkan penilaian siswa SMA Surabaya pada Gambar 1 menunjukkan tujuan yang dirumuskan pada modul PIK sebagian besar telah jelas. Gambar 2 merupakan hasil penilaian siswa SMA Surabaya tentang materi pembelajaran pada modul PIK. Berikut Gambar 2 tentang penilaian materi pembelajaran pada modul PIK.

Berdasarkan penilaian siswa SMA Surabaya pada Gambar 2 menunjukkan materi pembelajaran pada modul PIK sebagian besar spesifik, mudah dimengerti, dan mudah diingat. Gambar 3 merupakan hasil penilaian siswa SMA Surabaya tentang contoh materi pada modul PIK. Berikut Gambar 3 tentang penilaian contoh materi pada modul PIK.

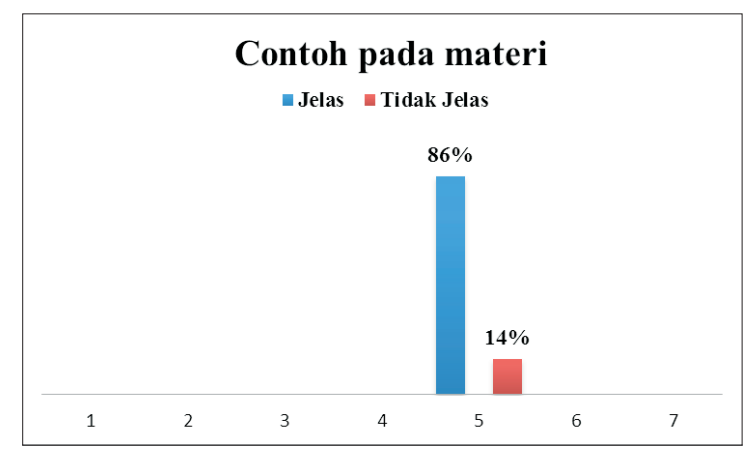

Gambar 3. Penilaian Siswa SMA Surabaya tentang Contoh Materi pada Modul PIK.

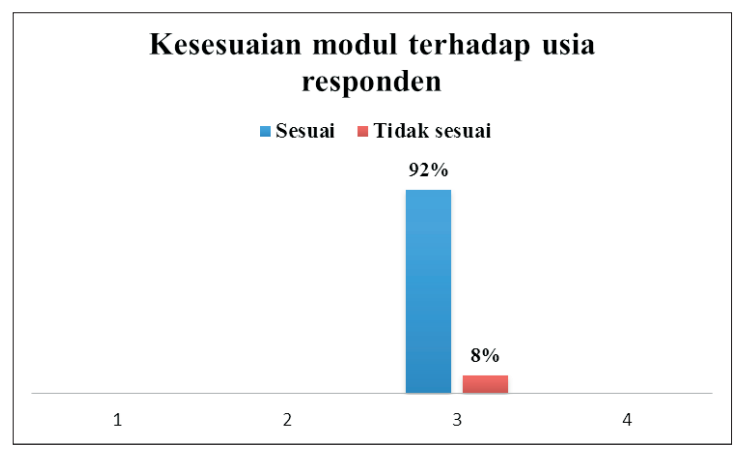

Gambar 4. Penilaian Siswa SMA Surabaya tentang Kesesuaian Modul PIK Terhadap Usia Responden.

Berdasarkan penilaian siswa SMA Surabaya pada Gambar 3 menunjukkan contoh materi pada modul PIK sebagian besar jelas. Gambar 4 merupakan hasil penilaian siswa SMA Surabaya tentang kesesuaian modul PIK terhadap usia responden berdasarkan karakteristik modul yang baik menurut Direktorat Pembinaan Sekolah Menengah Kejuruan (2008). Berikut Gambar 4 tentang kesesuaian modul PIK terhadap usia responden.

Berdasarkan penilaian siswa SMA Surabaya pada Gambar 4 menunjukkan kesesuaian modul PIK terhadap usia responden sebagian besar sesuai. Gambar 5 merupakan hasil penilaian siswa SMA Surabaya tentang Bahasa yang digunakan pada modul PIK. Berikut gambar 5 tentang Bahasa yang digunakan pada modul PIK.

Berdasarkan penilaian siswa SMA Surabaya pada Gambar 5 menunjukkan Bahasa yang digunakan dalam modul PIK sebagian besar

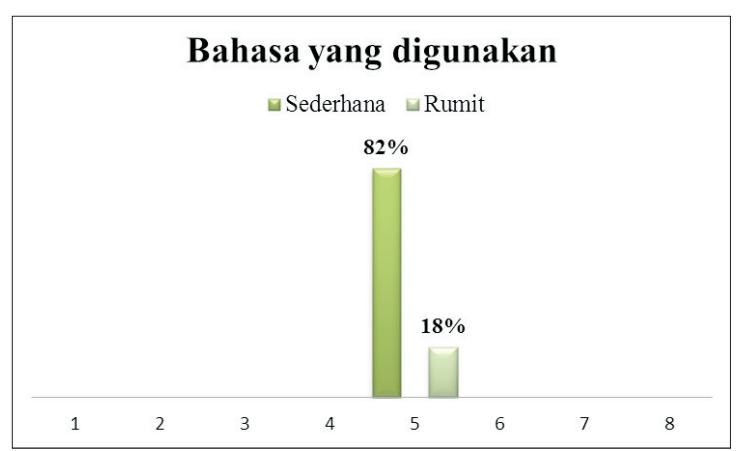

Gambar 5. Penilaian Siswa SMA Surabaya tentang Bahasa yang Digunakan pada Modul PIK. 


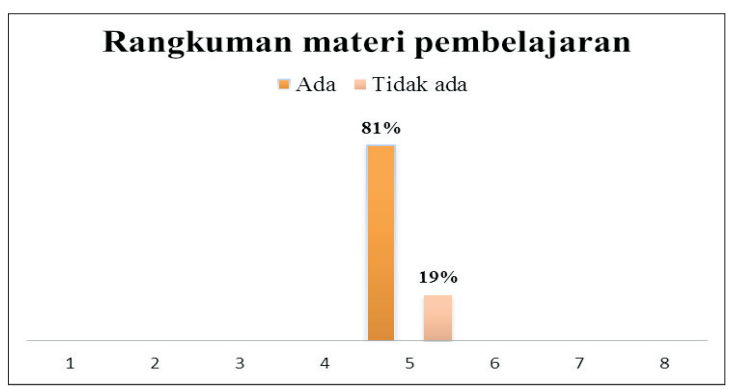

Gambar 6. Penilaian Siswa SMA Surabaya tentang Rangkuman Materi Pembelajaran pada Modul PIK.

sederhana. Gambar 6 merupakan hasil penilaian siswa SMA Surabaya tentang rangkuman materi pembelajaran pada modul PIK berdasarkan karakteristik modul yang baik menurut Direktorat Pembinaan Sekolah Menengah Kejuruan (2008). Berikut gambar 6 tentang rangkuman materi pembelajaran pada modul PIK.

Berdasarkan penilaian siswa SMA Surabaya pada Gambar 6 menunjukkan Rangkuman materi pembelajaran pada modul PIK sebagian besar telah tersedia.

Gambar 7 merupakan hasil penilaian siswa SMA Surabaya tentang instrumen penilaian pada modul PIK Surabaya berdasarkan karakteristik modul yang baik menurut Direktorat Pembinaan Sekolah Menengah Kejuruan (2008). Berikut Gambar 7 tentang instrumen penilaian pada modul PIK.

Berdasarkan penilaian siswa SMA Surabaya pada Gambar 7 menunjukkan instrumen penilaian pada modul PIK sebagian besar tersedia. Gambar 8 merupakan hasil penilaian siswa SMA Surabaya tentang referensi materi pada modul PIK Surabaya berdasarkan karakteristik modul

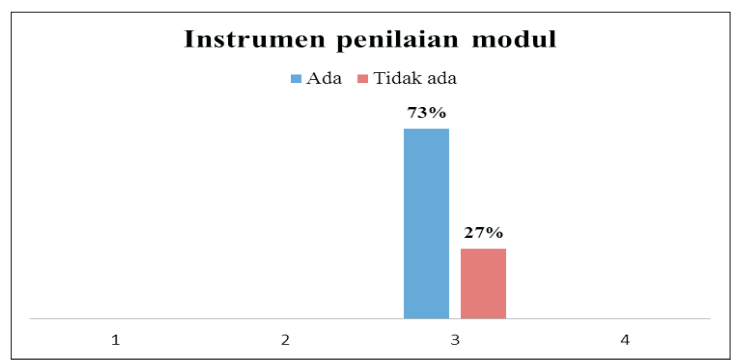

Gambar 7. Penilaian Siswa SMA Surabaya tentang Instrumen Modul PIK.

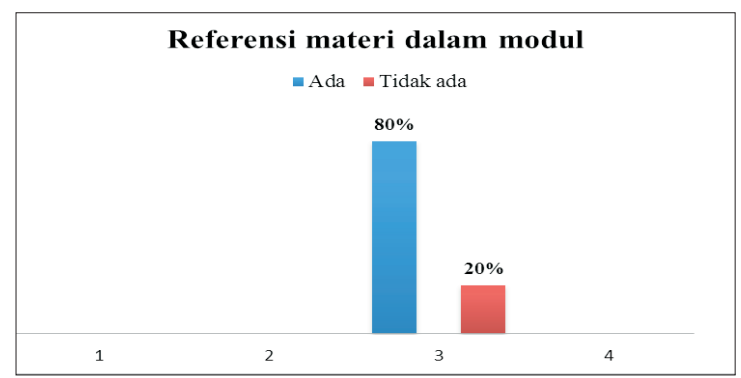

Gambar 8. Penilaian Siswa SMA Surabaya tentang Referensi Materi pada Modul PIK.

yang baik menurut Direktorat Pembinaan Sekolah Menengah Kejuruan (2008). Berikut Gambar 8 tentang referensi materi pada modul PIK.

Berdasarkan penilaian siswa SMA Surabaya pada Gambar 8 menunjukkan referensi materi pada modul PIK sebagian besar tersedia. Gambar 9 merupakan hasil penilaian siswa SMA Surabaya tentang tampilan modul PIK berdasarkan karakteristik modul yang baik menurut Direktorat Pembinaan Sekolah Menengah Kejuruan (2008). Berikut Gambar 9 tentang tampilan modul PIK.

Berdasarkan penilaian siswa SMA Surabaya pada Gambar 9 menunjukkan tampilan modul PIK sebagian besar menarik. Gambar 10 merupakan hasil penilaian siswa SMA Surabaya tentang penambahan ilustrasi pada modul PIK berdasarkan karakteristik modul yang baik menurut Direktorat Pembinaan Sekolah Menengah Kejuruan (2008).

Berdasarkan penilaian siswa SMA Surabaya pada Gambar 10 menunjukkan penambahan ilustrasi pada modul PIK sebagian besar kurang adanya ilustrasi.

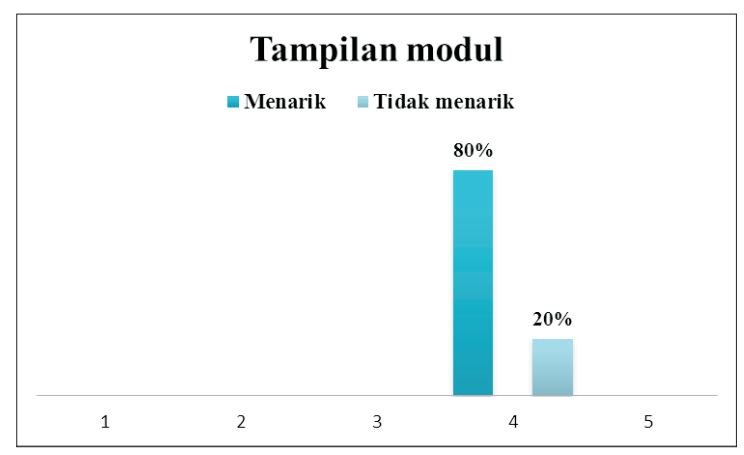

Gambar 9. Penilaian Siswa SMA Surabaya tentang Tampilan Modul PIK 


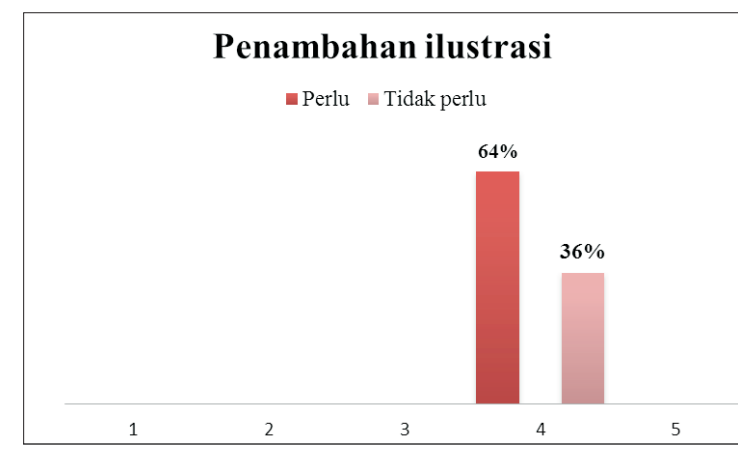

Gambar 10. Penilaian Siswa SMA Surabaya tentang Penambahan Ilustrasi pada Modul PIK.

\section{PEMBAHASAN}

\section{Karakteristik Siswa SMA Surabaya}

Sebagian besar siswa SMA Surabaya adalah siswa berumur 17 tahun. Remaja yang mengalami periode kritis masa pertumbuhan dan perkembangan dari anak menjadi dewasa terjadi pada umur 17-19 tahun (Saripediatri, 2010). Remaja pada umur 17-19 tahun merupakan masa antara remaja pertengahan dan remaja akhir (Notoatdmojo, 2007). Remaja pada masa ini mulai bereksperimen secara seksual dan ikut serta dalam perilaku berisiko, hal ini dapat dilihat dari jawaban kuesioner variabel sikap siswa SMA Surabaya tentang perilaku seks bebas remaja pada hasil penelitian. Sebagian besar siswa SMA Surabaya pada jawaban pre-test setuju dengan pergaulan bebas yang salah dan memiliki sikap yang cenderung untuk melakukan seks bebas.

Jumlah siswa SMA Surabaya dalam penelitian ini adalah 80 . Seluruh siswa SMA Surabaya memilih internet sebagai media yang digunakan untuk mencari informasi tentang seks bebas. Masa sekarang merupakan era kemajuan dan kecanggihan teknologi. Teknologi yang tadinya hanya digunakan untuk memenuhi kebutuhan kini telah menjadi gaya hidup masyarakat Indonesia. Salah satu kemajuan teknologi adalah internet.

Internet merupakan media komunikasi dan informasi modern yang dapat dimanfaatkan secara global oleh pengguna di seluruh dunia sehingga internet sebagai media informasi dapat menjadi sarana yang efektif dan efisien untuk melakukan pertukaran dan penyebaran informasi. Rahayu (2010), menjelaskan media internet paling banyak dipilih karena kemudahan dalam mengakses informasi tanpa perlu terhalang waktu, tempat, jarak, dan geografis. Media internet termasuk media yang menyediakan banyak informasi tentang seks, seperti cerita-cerita percintaan, berbagai model atau gaya dalam berhubungan seks, penjelasan orgasme, onani/masturbasi, ejakulasi, gambargambar wanita atau pria yang telanjang, pria dan wanita yang berhubungan seks juga dapat mempengaruhi perilaku seks bebas. Remaja lebih tertarik untuk mencari segala informasi yang berhubungan dengan seksualitas di internet secara mandiri tanpa pengawasan dari orang dewasa (Parkes, dkk., 2013).

Sebagian besar siswa SMA Surabaya memiliki kategori uang saku per hari antara Rp.8750-14650. Dengan kategori tersebut disimpulkan sebagian besar latar belakang ekonomi siswa SMA Surabaya adalah cukup, namun dengan latar belakang cukup tidak menggambarkan bahwa sikap siswa SMA Surabaya dapat meningkat secara signifikan.

\section{Perbedaan Sikap Siswa SMA Surabaya antara Pre-test dan Post-test tentang Perilaku Seks Bebas Remaja}

Tingkat sikap siswa SMA Surabaya termasuk dalam kategori baik dan sedikit mengalami peningkatan antara pre-test dan posttest. Tingkat sikap siswa SMA Surabaya 2016 tentang perilaku seks bebas remaja menunjukkan bahwa hasil sikap termasuk dalam kategori baik. Hal tersebut dapat dilihat pada hasil penilaian sikap yang terdiri dari kategori kurang, cukup, dan baik. Pada kategori cukup pre-test terdapat (14 siswa) namun pada post-test berkurang menjadi (7 siswa). Sedangkan pada penilaian sikap kategori baik menunjukkan pre-test terdiri dari (65 siswa) dan pada post-test siswa bertambah menjadi (72 siswa). Sehingga dapat disimpulkan bahwa tingkat sikap siswa SMA Surabaya mengalami sedikit peningkatan.

Ajzen (2005), mengatakan sikap merupakan suatu disposisi untuk merespons secara positif atau negatif suatu perilaku. Sikap terhadap perilaku ditentukan oleh belief tentang konsekuensi dari sebuah perilaku, yang disebut 
sebagai behavioral beliefs (Ajzen, 2005). Menurut Ajzen (2005), setiap behavioral beliefs menghubungkan perilaku dengan hasil yang bisa didapat dari perilaku tersebut. Sikap terhadap perilaku ditentukan oleh evaluasi individu mengenai hasil yang berhubungan dengan perilaku dan dengan kekuatan hubungan dari kedua hal tersebut (Ajzen, 2005). Secara umum, semakin individu memiliki evaluasi bahwa suatu perilaku akan menghasilkan konsekuensi positif maka individu akan cenderung bersikap favorable terhadap perilaku tersebut; sebaliknya, semakin individu memiliki evaluasi negative maka individu akan cenderung bersikap unfavorable terhadap perilaku tersebut (Ajzen, 2005).

Menurut Ajzen (2005) sikap terhadap perilaku didefinisikan sebagai derajat penilaian positif atau negatif individu terhadap perilaku tertentu. Sikap terhadap perilaku ditentukan oleh kombinasi antara behavioral belief dan outcome evaluation. Behavioral belief adalah belief individu mengenai konsekuensi positif atau negatif dari perilaku tertentu dan outcome evaluation merupakan evaluasi individu terhadap konsekuensi yang akan ia dapatkan dari sebuah perilaku.

Dapat disimpulkan bahwa individu yang percaya bahwa sebuah perilaku dapat menghasilkan outcome yang positif maka individu tersebut akan memiliki sikap yang positif terhadap sebuah perilaku, begitu juga sebaliknya. Sehingga hal tersebut menunjukkan bahwa sikap siswa SMA Surabaya dalam menilai suatu perilaku positif atau negatif tentang perilaku seksual pada remaja sedikit meningkat.

\section{Efektivitas Modul Terhadap Perubahan Sikap Siswa SMA Surabaya tentang Perilaku Seks Bebas Remaja 2016}

Terdapat perbedaan pada tingkat sikap siswa SMA Surabaya antara pre-test dan post-test. Perbedaan tersebut yaitu berupa peningkatan nilai secara hitungan manual namun secara hitungan statistik nilai rata-rata sikap responden menurun. Hitungan manual dengan melihat tabel 2 menunjukkan sikap responden sedikit meningkat. Sedangkan hitungan statistik mean rank sikap siswa SMA Surabaya diketahui pada pre-test adalah $(50,3500)$ dan pada post-test menurun menjadi $(50,0625)$. Selain itu, mulai Asymp. Sig sikap responden adalah $(0,659)$ yang berarti tidak terdapat perbedaan yang signifikan antara pre-test dan post-test.

Hasil penilaian responden terhadap konten pada modul berdasarkan kriteria modul yang baik sesuai penulisan Direktorat Pembinaan Sekolah Menengah Kejuruan (2008) menunjukkan bahwa modul tentang kesehatan reproduksi remaja, seksualitas dan permasalahan remaja memiliki kriteria yang baik, namun terdapat 1 (satu) kriteria yang belum terpenuhi yaitu perlunya ilustrasi dalam modul.

Direktorat Pembinaan Sekolah Menengah Kejuruan (2008) menyatakan bahwa karakteristik modul yang baik apabila telah memenuhi self instruction, self contained, stand alone, adaptif, dan userfriendly. Lima (5) karakteristik yang harus terpenuhi dirangkum dalam sepuluh (10) konten modul yang menggambarkan tiap karakteristik. Adapun konten modul tersebut adalah tujuan yang dirumuskan, materi pembelajaran, contoh pada materi, kesesuaian modul dengan usia responden, bahasa yang digunakan, rangkuman materi pembelajaran, dan penambahan ilustrasi.

Berdasarkan hasil penelitian sebagian besar tujuan yang dirumuskan dalam modul PIK telah jelas. Dengan adanya tujuan yang dirumuskan dalam modul dengan jelas sehingga pembaca maupun siswa SMA Surabaya dapat memahami maksud dari tujuan dicetaknya modul PIK. Selain itu, dengan adanya tujuan yang jelas siswa SMA Surabaya dapat mengetahui manfaat dari adanya modul PIK bagi permasalahan remaja.

Materi pembelajaran dalam modul PIK menurut penilaian siswa SMA Surabaya yaitu sebagian besar spesifik, mudah dimengerti, dan mudah diingat. Dengan materi pembelajaran yang spesifik, remaja maupun siswa SMA Surabaya mampu lebih mudah dalam memahami dan menangkap maksud dari materi pembelajaran dalam modul. Sehingga mampu membuat siswa SMA surabaya mendapatkan informasi yang sesuai dengan tujuan adanya modul PIK. Selain itu, modul PIK juga memiliki materi pembelajaran yang mudah dimengerti dan mudah diingat. Sehingga modul tidak hanya menambah informasi siswa SMA Surabaya namun juga 
dapat diimplementasikan dalam kehidupan sehari-hari. Contoh pada materi dalam modul PIK berdasarkan penilaian siswa SMA Surabaya sebagian besar jelas. Sama halnya dengan tujuan, dengan adanya contoh pada materi yang jelas mampu membuat siswa remaja maupun siswa SMA Surabaya dapat dengan mudah memahami dan mengerti dari materi yang ada dalam modul PIK.

Berdasarkan hasil penilaian siswa SMA Surabaya tentang kesesuaian modul dengan usia responden, sebagian besar siswa SMA Surabaya menyatakan bahwa modul sesuai dengan usia mereka. Modul PIK yang berisi tentang kesehatan reproduksi merupakan materi yang sensitif jika tidak sesuai dengan usia responden. Modul yang baik harus sesuai dengan usia responden agar tidak menimbulkan dampak yang tidak diinginkan seperti siswa mencari tahu dan mencoba hal-hal yang belum sesuai usianya pada modul.

Modul PIK menurut siswa SMA Surabaya sebagian besar telah menggunakan Bahasa yang sederhana. Dengan menggunakan bahasa yang sederhana dan tidak berbelit-belit mampu membuat siswa SMA Surabaya lebih mudah menangkap dan memahami isi dari materi pembelajaran dalam modul PIK. Selain itu, rangkuman materi pembelajaran dalam modul PIK telah tersedia. Dengan adanya rangkuman materi pembelajaran siswa dengan mudah mengerti inti dari materi dalam modul PIK.

Berdasarkan penilaian siswa SMA Surabaya, modul PIK perlu penambahan ilustrasi. Sebagian besar siswa SMA Surabaya menyatakan bahwa ilustrasi pada modul PIK kurang. Dengan adanya penambahan ilustrasi berupa gambar atau cerita pendek dalam modul PIK dapat membuat remaja maupun siswa SMA Surabaya lebih semangat dalam membaca modul karena modul yang hanya berisi tulisan akan terasa monoton dan siswa cenderung tidak mau membaca. Sehingga sangat diperlukan suatu ilustrasi dalam modul PIK agar modul lebih baik lagi.

Sehingga dapat disimpulkan modul PIK tentang kesehatan reproduksi remaja, seksualitas dan permasalahan remaja telah memenuhi kriteria berdasarkan Direktorat Pembinaan Sekolah Menengah Kejuruan (2008) namun belum efektif mengubah sikap siswa-siswa SMA Surabaya tentang perilaku seksual pada remaja.

\section{SIMPULAN DAN SARAN}

\section{Simpulan}

Kesimpulan yang didapat adalah sebagian besar siswa SMA Surabaya berumur 17 tahun, sebagian besar berjenis kelamin perempuan, sebagian besar memiliki kategori uang saku per hari antara Rp8750-Rp17450, dan riwayat pendidikan orang tua responden adalah sebagian besar pernah mengenyam pendidikan. Hasil pretest dan post-test sikap siswa SMA Surabaya menunjukkan bahwa sikap tentang seks bebas menurun dan tidak signifikan, sehingga modul PIK tentang kesehatan reproduksi remaja, seksualitas dan permasalahan remaja belum efektif dalam mengubah sikap siswa-siswa SMA Surabaya tentang seks bebas.

\section{Saran}

Siswa-siswi SMA Surabaya dan seluruh remaja Indonesia diharapkan dapat mengimplementasikan modul PIK yang telah diperbaharui pada kehidupan sehari-hari, sehingga modul PIK tidak hanya dibaca tetapi juga sikap siswa-siswi SMA Surabaya harus lebih berhati-hati dan berpedoman pada modul PIK agar terhindar dalam seks bebas.

Pihak sekolah dan guru BK diharapkan untuk menggunakan modul PIK yang telah direvisi sebagai acuan membimbing dan mengajar siswa-siswi SMA Surabaya. Hal tersebut diharapkan mampu meningkatkan sikap siswa-siswi SMA Surabaya tentang seks bebas. Sehingga siswa SMA Surabaya masih tetap perlu dalam pemantauan pihak sekolah dalam mengimplementasikan modul PIK dalam kehidupan sehari-hari.

\section{DAFTAR PUSTAKA}

Ajzen, I. 2005. Attitudes, Personality and Behavior. New York. USA: Open University Press.

Ajzen, I., \& Fishbein, M. 1980. Understanding Attitude and Predicting Social Behavior. New York: Prectice-Hall. 
Astria, A. 2014. Pengembangan Modul Pembelajaran Ips dengan Tema "Pemanfaatan Sumber Daya Alam (Sda)" Untuk Smp/Mts (Kelas Viii Semester 1). Skripsi. Universitas Negeri Yogyakarta. Tersedia di: http:// eprints.uny.ac.id/21856/3/BAB\%20II.pdf[14 September 2016]

Badan Kependudukan dan Keluarga Berencana Nasional. 2012. Kurikulum Diklat Teknis Pengelolaan PIK Remaja/Mahasiswa. Jakarta: Badan Kependudukan dan Keluarga Berencana Nasional.

Badan Kependudukan dan Keluarga Berencana Nasional. 2012. Saatnya yang Muda yang Berencana: Sebuah Profil Program Genre. Cetakan Ketiga. Jakarta: Badan Kependudukan dan Keluarga Berencana Nasional.

Badan Kependudukan dan Keluarga Berencana Nasional. 2013. Kurikulum Diklat Teknis Pengelolaan PIK Remaja/Mahasiswa. Cetakan Keempat. Jakarta: Badan Kependudukan dan Keluarga Berencana Nasional.

Badan Kependudukan dan Keluarga Berencana Nasional. 2011. Kajian Profil Penduduk Remaja (10-24 Tahun): Ada apa dengan Remaja?. Seri I no. 6. Jakarta: Pusat Penelitian dan Pengembangan BKKBN.

BPS, BKKBN, KEMENKES, MEASURE DHS. 2012. Survei Demografi dan Kesehatan Indonesia 2012. Jakarta: BPS.

Darmasih, R. 2009. Faktor yang Memengaruhi Perilaku Seks Pranikah pada Remaja SMA di Surakarta. Skripsi. Universitas Muhammadiyah Surakarta. Tersedia di $<$ http://etd.eprints.ums. ac.id/5959/1/J410050007.PDF> [12 Januari 2016].

Direktorat Pembinaan SMK. 2008. Teknik Penyusunan Modul, Seri Bahan Bimbingan Teknis Implementasi KTSP. Jakarta: Departemen Pendidikan Nasional.
Jasaputra, D.K, and Slamet, S. 2008. Metodologi Penelitian Biomedis. Edisi 2. [e-book] Bandung: Danamartha Sejahtera Utama. Tersedia di: <http://repository.maranatha. edu/2514/1/Metlit\%2520BAB\%2520III.pdf> [11 Januari 2016]

Notoatmodjo, S. 2010. Metode Penelitian Kesehatan. Jakarta: Rineka Cipta

Nursalam, 2008. Konsep dan Penerapan Metodologi Penelitian Ilmu Keperawatan. Jakarta: Salemba Medika

Prasetyo, Purnomo, Meirawati, Istikah, Hariyanti, dan Ikhsan. 2015. Modul PIK Pelatihan Perlindungan Anak Berbasis Sekolah. Surabaya: Yayasan Genta Surabaya

Rahayu, W. S. 2010. Analisis Pemanfaatan Situs Web Perpustakaan USU Untuk Kegiatan Akademik: Studi Kasus Pengguna Layanan Digital Perpustakaan USU. Skripsi. Universitas Sumatera Utara. Tersedia di <http://http://repository.usu.ac.id/ bitstream/123456789/22895/4/Chapter\%20 II.pdf $>$ [18Oktober 2016].

Saifuddin, A. 2007. Sikap Manusia Teori dan Pengukurannya. Yogyakarta: Pustaka Pelajar.

Saragih, D.O. 2015. Faktor-Faktor Yang Berhubungan Dengan Perilaku Seks Pranikah Remaja Di Sma Negeri 5 Pematang siantar Tahun 2015. Skripsi. Universitas Sumatera Utara. Tersedia di: $<$ http://repository.usu.ac.id/ bitstream/123456789/49566/5/Chapter\%20I. pdf $>$ [14 September 2016]

Wibowo, F.T. 2013. Pengembangan Modul Pembelajaran Kompetensi Pemesinan Bubut Cnc Untuk Siswa SMK. Skripsi. Universitas Negeri. Tersedia di: http://eprints.uny. ac.id/20305/1/Fendi\%20Tri\%20Wibowo\%20 09503244038.pdf [15 September 2016] 